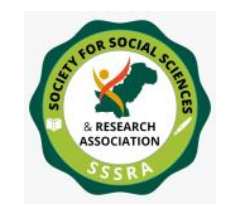

Pak. Journal of Int'L Affairs, Vol 4, Issue 4 (2021) History and Background of Madrassah Education ...

\title{
HISTORY AND BACKGROUND OF MADRASSAH EDUCATION IN PAKISTAN
}

\author{
Dr. Surriya Shahab \\ Institute of Social and Cultural Studies \\ Bahauddin Zakariya University \\ Multan - Pakistan. \\ suriishaque786@gmail.com
}

\begin{abstract}
Pakistan has been traditional and modern education systems since its inception. The traditional education system or traditional Islamic schools which are called Madaris (Madrassahs) have been growing rapidly since 1980s during the Soviet intervention into Afghanistan and Imam Khumeni Revolution in Iran. The madaris have been influenced by the wave of Islamic fundamentalism from Iran and Afghanistan. After the Taliban Government in Afghanistan in late 1990s, the Deoband Madaris in Pakistan came gradually under the sway of the anti-West Taliban Movement. In 2000, there are more than 50,000 Madrassahs in Pakistan but only 4,350 were registered. The history of Madrassahs education in Pakistan has been originated by the advent of Islam and Arabic culture to India with conquering of Sindh by Muhammad bin Qasim in 712 A.D. After the formation of Muslim rule at Delhi in 1208 A.D., a quarter of Indian-subcontinent population had converted to Islam over the next five centuries and Madrassahs were established in India. Those madaris had been providing education among Muslims of India from 1208 A. D. to 1757 A. D. till the British power in India. The Madrassahs in Pakistan are alleged to be nurseries to produce religious extremists. The purpose of this paper is to highlight the history and the changing pattern of Madrassahs Education in Pakistan. The paper is also examining the socio-political framework of Pakistan under which the Madrassahs are working.
\end{abstract}

Keywords: Madrassahs, Pakistan, Muslims, Education, Government.

\section{Introduction}

After the birth of Islam, Prophet Mohammad Peace Be Upon Him actively participated to promote education. In Dar Al Arqam at the base of Mount Safa, Prophet himself 


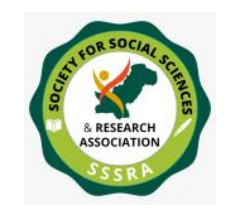

Pak. Journal of Int'L Affairs, Vol 4, Issue 4 (2021) History and Background of Madrassah Education ...

established the first school. The first students from the first educational institution in Islam were Abu Bakr RA, Omar (RA) and the other companions of prophet (Sattar, 2002). After the Hijra to Holy City of Medina, Prophet directed Ibn- e- Umme Maktom and Mosaab bin- Umair to take the responsibility of educating and spreading Islam. As Muslims took initiative to spread knowledge, they brought over 60-70 prisoners of war from the Zagwa (battle) of Badr and in exchange for ransom for their lives assured them to teach 10 Muslim children. Getting knowledge is an important part of the Muslim values. From the beginning of the Prophet Hood of the Holy Prophet (PBUH), the holy verses Quran were oral.

The Holy Quranic verses got the attention of the people of Mecca and they accepted Islam and memorized the Quran. With the passage of time, Islam expanded and it became an obligation to save this divine knowledge of Quran, so the Holy Quran was written down called "Surah" and separated into different parts. This compilation became the source of knowledge i.e. Holy Quran”. From the very first day, Islam focused two types of knowledge, knowledge from Allah called Revelation and knowledge of earth, Reveled Knowledge comes direct from Allah Almighty and knowledge of earth is to be explored and compiled by human. Islam considers these two types of knowledge and emphasizes its believers, to go and search for knowledge (Boyle, 2002).

According to Muslims, the Holy Quran is the undoubted word of Allah; most respected and hence cannot be changed. It must be memorized from IST chapter to last. When a person has memorized it, then he/she follows and acts upon the commands of Allah's message for life time. A person who memorized the Quran must carry the verses of Allah's message in his/her heart and it's his duty to spread the Quran. According to Islam getting the knowledge of earth is also necessary because the knowledge of earth helps in understanding of Quranic knowledge and motivates believers to spend their life in a productive manner. After reading the reason given above, everyone can understand why mosques came to be the main learning center for Muslims in the beginning of Islam and this practice is continuing till date. It was the Masjid (mosque) where Holy Prophet (PBUH) would motivate people to listen to the divine verses and their interpretation (Ahmad, 1987). Masajid(mosques) were the places where Quran was compiled. It was here, where early believers searching to solve their issues under the light of Holy Quran knowledge. The Masjid was the first madrassah in Islam. During the early age of Islam, there was no formal way of action and everyone who could memorize the Holy Quran could be the Imam in congregation and show the right path to believers. The scholars of Quran would mostly spent their times in masjid, discussing and increasing their knowledge of Quranic teachings and rest of the people who could not have much time for this activity simply gets the help and guidance of these scholars in daily matters. After the 


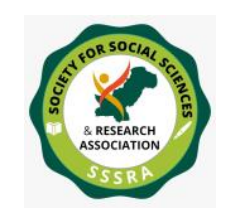

Pak. Journal of Int'L Affairs, Vol 4, Issue 4 (2021) History and Background of Madrassah Education ...

death of Muhammad (PBUH), believers faced different problems for which no solution could be found in the divine realia and the messenger of Allah was not there to guide them, the Muslim researchers, sought solutions in the quotations and practical life of God's messenger. This led to the development of following "the Sunnah", the knowledge of deeds of holy messenger and "Hadith", the sayings of Holy Prophet (PBUH). The masjid is still to be the center of knowledge, even after the Holy Prophet (PBUH). This masjid based understanding and getting of knowledge worked a vital role for Muslims of Arab , as they lived in tribes and tribal values combined with the teachings of revealed knowledge was enough to govern the lives of people as they had common language and culture. The second phase of the Islamic education began with the reign of Hazrat Umar Bin Abdul Aziz the eighth Khalifa of the Umaiya lineage.

During this time, state proclamations were made throughout the country and wages and allowances for teachers and scholarships for students were arranged ( Faridi, 2002). Separate learning rooms for students and teachers were established in the mosques during this period as well. The whole of Arabia and Iran was transformed into Muslim centers of learning, knowledge and research. The arrival of the Arabs through Bin Qasim conquest of the Indus had a similar influence on the Indian localities as well. However, the Muslim conquest of India did not succeed in presenting a superior educational system to the Indian subcontinent. Instead, following the traditional Indian educational institutions teaching religion and Sanskrit, they established maktabs and Madrassahs (Islam, 2005). The entrance of Arabs after the successful battle of Sindh by bin Qasim had same effect on Indian areas as well. The large number of Arabs came to India in $11^{\text {th }}$ century, the invasion of Muslims and increase in their population expanded the growth of madrassah in major cities like Delhi, Lucknow, Ajmer, Rampur, Multan, Uch, Dhaka and other major cities . The Madrassahs were grown up as school of learning in the $11^{\text {th }}$ century (Makdisi, 1981). As stated in the book "Tareekh-e- Farishta", the first madrassah was came into being in Multan in $11^{\text {th }}$ century (Momen, 2006).

\section{Madrassah Curriculum}

A Quranic school can be described as the lowest level of learning in Islamic education. The curriculum in a Quranic school is usually the Quran only. Every Muslim child, girl and boy, is expected to read and recite the Quran early on. A typical model of Quran school which is common from Central Asia to China, from India to Arabia and from South Africa to the North is a small room, usually attached to a mosque, where a teacher, usually male, teaches students to read and in some cases memorize the Quran in Arabic whatever the child's mother tongue. Students usually finish the Quran in about three to four years. The students vary in ages from 4 years to 16 or more years. If it is a male teacher, then girl 


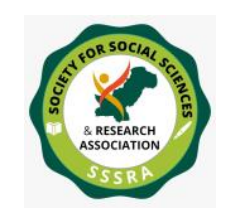

Pak. Journal of Int'L Affairs, Vol 4, Issue 4 (2021) History and Background of Madrassah Education ...

students do not study with him after reaching a certain age (typically 9+ years). A Quran school usually functions during hours that are most compatible to the time and work schedules of the students - either first thing in the morning or late in the afternoon. In most countries of Asia and Arabia, students go to the Quran School either before or after their school day in a regular public school. In some parts of West Africa, for poor people, Quran schools are the only avenue of obtaining some literacy. Each Quran school on average has 40-60 students at one time and the number may decrease or increase depending on the population of the area where it is located. The Quran teacher is usually a Hafiz Quran - the one who has memorized the text and teaches by one-on-one coaching technique. The teacher also teaches by organizing small groups depending upon the age and level of learning of the student. If the number of students is high, the teacher utilizes the technique of peer tutoring, where those students who have mastered a certain level of the Quran are made to teach the little ones.

On a typical day, the teacher would start by asking students to recite what was taught the day before. After ensuring that the student has learned to read and pronounce the Quran words in an acceptable manner, he/she reads with the student the next few paragraphs three or four times, until the student begins to rightly pronounce and read the new text Quran schools are informal education systems. This school sector is not centrally controlled nor does it have any clearly stated goals other than the fact that the students should be able to read and pronounce the Arabic words correctly. The in-depth learning of the Quran at the Quran school level is not required. It is only at the Madrassa level- the more detailed Islamic learning level - where students study the Quran in its entirety, meaning, with full understanding of all aspects and detailed interpretation. The common curriculum in Madrassahs, in all regions, is Islamic studies and acquisition of greater understanding of Islamic principles that govern day-to-day lives of the Muslims. Therefore, subjects such as Fiqqah - Islamic law, Hadith - Prophet's saying, Sunnah Prophet's traditions, Tafseer interpretation of the Quran, and logic form the crux of Madrassah curriculum. Whereas, most Madrassas in Pakistan teach only religious subjects, many Madrassahs, such as the ones in Egypt, Indonesia and Bangladesh, also teach secular subjects. There are three main types of religious institutions in Pakistan: Quran schools (where only the Quran is taught), Mosque schools (where both Quran and secular subjects are taught) and Madrassahs (where only Islamic learning takes place).

\section{Quran Schools}

Every Muslim child in Pakistan is expected and encouraged to read the Quran either in a mosque or at home. Quran schools usually function in a mosque where the Mullah (Religious Teacher) teaches the Quran to children, both boys and girls. At the basic level, 


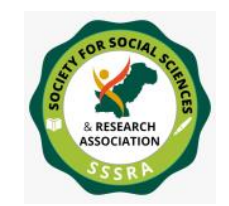

Pak. Journal of Int'L Affairs, Vol 4, Issue 4 (2021) History and Background of Madrassah Education ...

the Quran is taught in words only and no translation or interpretation is provided to students. The end objective is that all Muslims must be able to read the Quran in Arabic even if they do not understand the language itself. Students are expected to try to understand the Quran when possible but not much is actually done to impart detailed knowledge of the Quran to the student in Quran schools. Quran schools offer classes at various times - evening, morning, afternoon - to accommodate the time schedules of teachers and students.

\section{Mosque Primary Schools}

Due to a lack of resources to provide schools in every village, in the mid 80's the Government of Pakistan experimented with the idea of converting some Quran schools into mosque primary schools in rural areas. The plan was to add some additional subjects such as basic Urdu and Mathematics, which would be taught to the students by the local Imam (Mullah). The plan faced serious challenges because the local Imams were not academically prepared to teach Urdu and Mathematics since many of them had not attended formal secular schools and the Government did not provide any training to prepare them for the new task. While some mosque schools closed down, some also survived. Currently, there are approximately 25,000 mosque primary schools in Pakistan. Studies on their efficacy are not available.

\section{Madrassah}

The mission of most Madrassahs in Pakistan is to prepare students for religious duties. Adhering to strict religious teachings, Madrassahs teach Islamic subjects such as the Quran, Islamic law and Jurisprudence, Logic and the Prophet's traditions. Depending upon the levels of the Madrassahs (primary, middle or high), the concentration of religious teachings is increasing. Hafiz-e-Quran (the one who memorizes the Quran fully) or Qari (the one who can recite the Quran with good pronunciation and in a melodic tone) are produced at the lower level of Madrassahs. The higher levels of Madrassahs produce Alim - the Islamic scholar and/or teacher. An Alim certificate from a Madrassa is equivalent to an MA degree in Islamic Studied or Arabic from a regular University. A Madrassah student after graduating from grade 10, is qualified enough to declare Fatwas - religious edicts. Those students who enroll in Madrassahs full time do so with the knowledge that they will become well versed in religious studies only and will find jobs in the religious sector since very few Madrassahs supplement religious education with secular subjects. There are five major Islamic schools of thought in Pakistan: Deobandi, Barelvi, AhleHadith, Salafi, and Shia. Each sect has their own Madrassahs in which they teach their own version of Islam. The two main sects of Sunni Islam - Deobandi and Barelvi - 


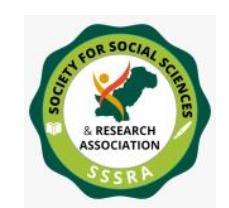

Pak. Journal of Int'L Affairs, Vol 4, Issue 4 (2021) History and Background of Madrassah Education ...

dominate the Madrassas system in Pakistan (International Crisis Group, 2002). Deobandi schools are most commonly found along the Afghan-Pakistan border and within the city centers. Now in South Punjab, the Deobandi madaris are numerically higher than the other sects. The Deobandi and Barelvi sects originated in the colonial Indian sub-continent in response to the perceived imperial plot to destroy Islam and its followers by enforcing its own version of education. The Deobandi sect is considered the most conservative and antiwest.

Madrassahs in Pakistan are a product of Soviet-Afghan war. For most of Pakistan's history, Madrassahs numbered in the low hundreds and focused on training the next generation of religious leaders. Beginning in the mid 70's, the number of Madrassahs began to grow. The reason was that the government of Pakistan failed to provide education to the growing number of students. The rise of Jamat-e-Islami (an Islamic political party), and the active support from the Bhutto Government to essentially declaring Pakistan a theocracy, led to the expansion of Madrassahs where children could come for religious education free of cost. At the same time, the events in neighboring Iran were also influencing the process of Islamization of Pakistan. The number of Madrassahs grew at an even greater rate in the mid-80s under Zia's regime, with financing from the Pakistani government, and the CIA. Large theological seminaries were established along the AfghanPakistan border to create a cadre of religiously motivated Mujahidins to fight the Soviets in Afghanistan. Students in these seminaries were taught to fight the 'Godless' Russians and ensure that Afghanistan is freed to be established as a good religious state (Haqqani, 2003).

Students learned basic mathematics by counting dead Russians and hand grenades. Religious fervor, support from the super-powers resulted in the defeat of the Soviet Union in Afghanistan. Then the military dictatorship fell in Pakistan. As subsequent governments in Pakistan, who were engaged in inter-political bickering, were unable to fully control these Madrassas financially, additional funds started flowing in from private individuals and Islamic charities. At the same time, CIA abandoned these institutions and thought that now that the Soviet Union is gone so will all the lessons from the minds of the Madrassah students who were trained to fight the Soviets. In addition, the inability of the Government of Pakistan to provide education for all and the precarious political situation in Afghanistan kept the Madrassah system alive in Pakistan. More and more Mujahidin were recruited to fight for the ouster of the corrupt governments in Afghanistan and Holy Wars in other places such as Kashmir, Bosnia etc. In addition to Madrassahs that were established to support the Afghan conflict, other sectarian Madrassahs, flourished during the same time in Pakistan. The main purpose of these sectarian Madrassah was to guard and spread their version of Islam. An interesting product of this transition in the Islamic education system in Pakistan is that after the fall of the Russian Empire, the focus of hatred in Madrassahs 


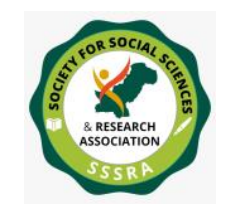

Pak. Journal of Int'L Affairs, Vol 4, Issue 4 (2021) History and Background of Madrassah Education ...

shifted from Russia to the West in general. The boundary of hatred that was earlier limited to Russia, the Godless enemy, expanded to include the West in general and the United States in particular. Jessica Stern has cautioned the world about "the kind of "education" imparted by these "Schools of Hate"(Madrassahs) and their role in creating a mindset for jihad" (Stern, 2000).

The Israeli-Palestinian conflict was used as a pre-curser by the Arab financiers from Saudi Arabia and Kuwait to create a cadre of Muslim fighters who would not only, somehow, restore the land to the Palestinians but also strengthen Islam by restoring it to its original state - the puritanical Wahabi version. Those Madrassahs that tried to propose the teaching of secular subjects so that their students would have some marketable skills were strictly forbidden to do so by the patrons in Saudi Arabia and Kuwait. Thus, Pakistani Madrassas came under a vicious circle from which there was no way out. The Human Rights agencies condemned the conditions and environment of Madrassahs due to crowded and undisciplined (Kepel, 2002).

\section{Conclusion}

In summary, the inability of the Pakistani government to meet the demand of education by young Muslim males; economic deterioration in Pakistan; the events in Afghanistan; open financial support for expanding religious education by Saudi Arabia and Kuwait; and U.S. interests in terms of using Mujahidins for the fall of the Soviet Union; played a crucial role in bringing the Madrassa system in Pakistan to where it is now. As the saying goes, too many chefs can destroy the cake. The same thing happened to the religious education in Pakistan - there were too many players who were following their own recipes and not paying attention to the final product. The Madrassahs are providing free education and accommodation to the students so poor families in Pakistan who cannot afford to admit their children in private and public schools are preferred to send their children in Madrassahs in Pakistan. After Afghan Jihad and Iranian Revolution of 1979, the Madrassahs were speedily increased because the Madrassahs got extensive funds from Iran, Saudi Arabia, UAE, Iraq and Libya. 
Pak. Journal of Int'L Affairs, Vol 4, Issue 4 (2021) History and Background of Madrassah Education ...

\section{References}

Boyle, H. (2002). Quranic School Strategy and Mini Needs Assessment. Trip Report to Nigeria.

Faridi, A. H. (2002). Madrasah Education in Bangladesh. Bangla Academy.

Haqqani, H. (2003). Presentation on the Capitol Hill, February 2003.

International Crisis Group. (2002). Pakistan: Madrassas, Extremism and the Military.

Islam, S. (2005). Modern Education in Bangladesh: Historical Background. In Lekhak Shibir (Ed.), Education in Bangladesh: The Past, the Present, the Future.

Kepel, G. (2002). Jihad: The Trail of Political Islam. The Belknap Press of Harvard University Press.

Makdisi, G. (1981). The Rise of Colleges: Institutions of Learning in Islam and the West. Edinburgh University Press.

Momen, A. (2006). Madrasah Education in Bangladesh: Background, Present Status and the Position of Women. Nari Pragati Sangha.

Munir Ahmed, M. (1987). Islamic Education Prior to the Establishment of Madrassa. Journal of Islamic Studies.

Sattar, A. (2002). The History of the Aaliyah Madrassah. Islamic Foundation.

Stern, J. (2000). Pakistan's Jihad Culture. Foreign Affairs, 79(6), pp.234-243. 